\title{
Teacher Management in Early Children Education
}

\author{
Dita Dewi Lestari ${ }^{1}$ \\ ${ }^{1}$ FKIP-Universitas Muhammadiyah Surakarta
}

\begin{abstract}
This study aims to describe the planning, recruitment, coaching, and development at Surya Ceria Aisyiyah kindergarten, Cangakan, Karanganyar. This research is a qualitative descriptive study. Data collection uses observation techniques, interviews, and documentation. Test the validity of the data using technical triangulation and source triangulation. Data analysis using the model of Miles and Huberman namely the reduction stage, the stage of data presentation, and drawing conclusions.

The results of his research are (1) Planning in Surya Ceria Aisyiyah PAUD using job analysis and job analysis. (2) Recruitment of teachers in kindergarten Surya Ceria Aisyiyah, namely forming a committee for the recruitment of prospective new educators, announcements, administrative selection. The selection process for applicants in kindergarten Surya Ceria Aisyiyah includes administrative selection, written test, interview test, microteaching test. after the test ends, the overall test results will be discussed and determined which ones are accepted and rejected. Applicants who pass the selection face the school principal to be given directions related to the work contract and salary; (3) Guidance and development of educators through the identification of educator needs with evaluation methods. Forms of coaching and development in kindergarten Surya Ceria Aisyiyah Cangakan Karanganyar, namely supervision of school principals, seminars, workshops, training, In House Training, organization, training, visits, and comparative studies, further education.
\end{abstract}

\section{KEY WORDS}

management of education, management of teacher teachers, early childhood education

CORRESPONDING AUTHOR:

email: ditadewi96@gmail.com

Manuscript submitted May 01, 2020; accepted June 7, 2020.

Copyright: (2020 This is an open access article under the terms of the Creative Commons Attribution License, which permits unrestricted use, distribution, and reproduction in any medium, provided the original author and source are credited.
ECRJ (Early Chilhood Research Journal)

ISSN Numbers: Print, 2655-6448; Online, 2655-9315

\section{ADDRESS}

Website: http://journals.ums.ac.id/index.php/ecrj Address: Pendidikan Guru PAUD Universitas Muhammadiyah Surakarta

A. Yani Street No. 1, Pabelan, Kartasura, Surakarta, Indonesia Telp. +62-271-717417 ext.

Email: ecrj@ums.ac.id

\section{INTRODUCTION}

In a collaboration group, management is needed. Management is an effort in organizing an institution so that goals can be achieved effectively and efficiently. Management is also needed in managing an educational institution. One scope of educational management is the management of educators (Baharuddin : 2010). The management of educators is very important for the world of educators. This is because teachers are the spearhead of education (Komarian dan Cepi : 2006). In this globalization era, the management of educators plays an important role in efforts to 
improve the quality and professionalism of educators, so good management is needed. Through good management of educators, the institution will get the right educators, happy to work, and not easily move. Educators who are not qualified, are not comfortable carrying out assignments, and frequently move places will be an obstacle in educating children. Educating early childhood requires an appropriate management system, improving the quality of education must begin with professional educators. Therefore educator management becomes urgent.

Educator management aims to empower educators effectively and efficiently to achieve optimal results, but still in pleasant conditions. Educator management has a scope covering the planning of educators and selection of applicants (Manullang : 2006). From this scope, management activities of educators include planning, recruitment, coaching, and developing educators.

Educator planning is an effort to determine the policies and needs of educators both quantitatively and qualitatively in the present and future. The preparation of the educator's plan needs to be carried out in two stages namely job analysis and job analysis (Mulyasa : 2006). Job analysis is formulated in different editorials, although in general the meanings and meanings are not different from one another, instead they complement each other. Job analysis is the process of gathering information about each position, which is useful for realizing the goals of the institution (Nawani : 2011). Job analysis is done to get a description of the job. And become the basis of the next process of human resource management (Goffin et al 2011). ${ }^{6}$ Job analysis is a process of gathering, analyzing, and then determining information relating to the content of work and other management activities. The job analysis process focuses on determining the purpose for which information is used (Armstrong : 2014)

Recruitment is a planned activity in attracting some qualified individuals needed to carry out the tasks that exist in a school operational district (Jones and Walters : 2008) Similarly, recruitment is a process or action taken by the company to get additional employees through several stages (Siagian : 2002). From the description above it can be concluded that the recruitment of educators is a process carried out by an educational institution to get educators with certain characteristics according to the needs of the institution. The recruitment process of educators is carried out in 4 stages, namely the preparation of teaching staff, the dissemination of announcements for educator recruitment, recruitment of new educators and selection of applicants (Bafadal : 2002). The steps in selecting teacher recruitment are a selection of application letters, filling in an application form, reference examination, preliminary interview, acceptance test, psychological test, health test, final interview of the direct supervisor, and deciding to be accepted or rejected (Hasibuan : 2007).

Coaching is to manage and control employees while carrying out work in an institution or school. Development is an effort to improve current and future achievements by providing knowledge, changing attitudes, or increasing skills (Hamid : 2014). The guidance 
and development provided by educators have stages of analyzing needs, composing instructional designs, authorizing training programs, implementation stages, evaluation stages and follow-up (Sukirman : 2000). Forms of guidance and development for PAUD educators vary in kind depending on the needs of the school. Its activities include supervising school principals, apprenticeship programs, school partnerships, seminars, workshops, continuing education, forming teacher discussion forums, forming technological works or artworks, internal coaching by schools.

\section{RESEARCH METHOD}

This research uses a descriptive qualitative approach. The research design uses a narrative research design. This research was carried out in Kindergarten Surya Ceria Aisyiyah, Cangakan, Karanganyar. Data sources in this study are the principal and teachers. Data collection techniques used were observation techniques, interview techniques, and documentation techniques.

The observations made in this study were non-participant observations, the researcher was not involved in the research subject's activity and was only an independent observer. The interview used is a guided interview where the interview only contains the main issues to be investigated, then the interview process takes place following the situation. While documentation is used to collect written information and photographs to complement the use of observation and interview techniques.
The validity of the data used in this study uses a credibility test. The method is done by using source triangulation and technique triangulation. Data analysis techniques using the model of Miles and Huberman, namely the data reduction stage, the stage of data presentation, and the stage of decision making and verification (Sugiyono : 2012)

\section{RESULTS AND DISCUSSION}

The results of research and data analysis relating to planning, recruitment, coaching, and development in Kindergarten Surya Ceria Aisyiyah, Cangakan. Karanganyar.

Planning in Kindergarten Surya Ceria Aisyiyah uses job analysis and job analysis. Analysis of the position of an educator is divided into two namely class teacher and teacher of the BCCT method. In a class there are two teachers with the same number of students each year, between 19-20 children for kindergarten services and 14-15 children for family planning services, this is based on the ratio of teachers in early childhood of education, which is 1:15. Job analysis between the class teacher and teacher center based on the workload given by each teacher. However, the frequency of effective working hours between class teachers and center teachers is the same.

Current planning can be used to increase the likelihood of achieving goals and better decisions. In other words, planning can minimize unexpected possibilities. this is in line with the theory put forward by Henry Fayol where one of the guidelines in management is planning (Musfah : 2017). Likewise with the 
planning of educators. The existence of an educator's plan determines what and how the work is done. to make the job description required analysis to assess an appropriate position. Analysis of the position of an educator is done to match the work with educators, find out the workload needed, and become the foundation in the implementation of educational management. This is also in line with the study of Jauharotul and Mulyadi (2017) that one of the planning of educators is the analysis of the position of educator so that he is able to analyze the strengths and weaknesses.

The next educator management activity is the recruitment of educators. The process of recruiting new educators in Kindergarten Surya Ceria Aisyiyah in the first stage formed the committee for the recruitment of new educator candidates, then the announcement of new recruitment announcements where the distribution was adjusted to environmental and school conditions, the committee accepted and selected application files based on predetermined criteria. This is in line with Bafadal's explanation of the recruitment process of educators (Bafadal : 2003).

The selection process for applicants in Kindergarten Surya Ceria Aisyiyah involves selecting the application file by predetermined criteria. For applicants who pass directly take the written test, interview test and microteaching. after the test ends, the overall test results will be discussed and determined which ones are accepted and rejected. Applicants who pass the selection face the school principal to be briefed about the work contract and salary.
Recruitment of educators is carried out to find educators who fit the given position. Educators who meet the specified requirements are one of the keys to business success. Educators who can carry out their various functions will produce school performance that is beneficial in the education process. This is following the management concept of "The Right Man in the Right Place" ie placing the right educator will benefit educational institutions (Nasruji : 2017)

Recruitment was carried out to find educators following established criteria to get quality educators. The recruitment process at Kindergarten Surya Ceria Aisyuyah, Cangakan, Karanganyar is in line with the "mating theory of recruitment" theory which institutions and prospective educators alike seek. Educational institutions are looking for new educators and applicants looking for work so the two meet (Muslimah : 2019)

The last management activity is coaching and development. coaching and development of educators in Kindergarten Surya Ceria Aisyiyah, Cangakan, Karanganyar through identifying the needs of educators in advance with the evaluation method. The headmaster's identification of the needs of the educator then discussed with the school coordinator team. This discussion is related to what activities are given by the educator, the implementation schedule to the educator, the schedule and details of the activities, and follow-up of the activities that have been carried out. Forms of coaching and development in PAUD Surya Ceria Aisyiyah Cangakan Karanganyar, namely supervision of school principals, seminars, workshops, 
training, In House Training, organization, visits, and comparative studies, further education.

There are several reasons for coaching and development carried out including rerefreshing. In working, there must be boredom, so there needs to be a refreshment that covers all the competencies of educators, especially PAUD educators. Also, coaching and development are carried out when the skills of educators are inadequate. Especially now educators are required to be able to master the technology so that the learning media given to children is diverse. New positions and tasks so training needs to be done. This is following the concept of "Peter principle" ie the inability to increase if faced with a new position or new tasks so that people need to be trained (Schaap : 2019).

\section{CONCLUSION}

Based on the results of data analysis and discussion about the management of educators in Kindergarten Surya Ceria Aisyiyah, the researcher can conclude, namely

a. The planning stage of educators uses job analysis and job analysis.

b. The educator recruitment process includes forming a committee for implementing new teacher admissions, distributing announcements, selecting application files. The selection steps in PAUD Surya Ceria Aisyiyah, namely (1) selecting the application by predetermined criteria; (2) taking written tests, interviews and microteaching; (3) the results of the whole test are discussed and determined which are accepted and rejected; (4) applicants who qualify to face the headmaster relating to salaries and employment contracts.

c. The steps of educating and developing educators are analyzing the needs of educators through evaluation. An analysis of the needs of educators is carried out by the principal then discussed with the school coordinator team. Forms of coaching and development are supervision of school principals, seminars, workshops, education, and training, In House Training, organization, internships, visits and comparative studies, further education.

\section{REFERENCES}

Baharuddin. 2010. Teori Belajar dan Pembelajaran, Jogjakarta: Ar-Ruzz Media

Komariah, Aan dan Cepi Triatna. 2006. Visionary leadership, Menuju Sekolah Efektif. Jakarta: Bumi Aksara

Manullang, M. 2006. Manajemen Personalia. Yogyakarta: gadjah Mada University Press

Mulyasa, E. 2006. Manajemen Berbasis Sekolah. Bandung: Remaja Rosdakarya.

Nawawi. 2011. Manajemen SUmber Daya Manusia: Untuk Bisnis Yang Kompetitif. Yogyakarta: Gajahmada University Press

Goffin. et.al. 2011. Choosing job-related personality traits: Developing valid personality-oriented job analysis. Personality and Indovidual Differences. 51(5),pp. 646-651

Armstrong, M. 2014. A Handbook of human resource managemenet practice (10th ed). London: Kogan Page) 
Jones, James. J dan walters, Donald. L. 2008. Human Resource Management Education. Yogyakarta: Q Media.

Siagian, S. P. 2002. Kiat Meningkatkan Produktivitas Kerja. Jakarta: Rineka Cipta

Bafadal, Ibrahim. 2003. Manajemen Peningkatan Mutu Sekolah Dasar, Dari Sentralisasi menuju Desentralisasi. Jakarta: Bumi Aksara.

Hasibuan, Malayu. 2007. Manajemen Sumber Daya Manusia Perusahaan. Bandung: PT Bumi Aksa

Hamid, Sanusi. 2014. Manajemen Sumber daya Manusia Lanjutan. Yogyakarta: Deepublish

Sukirman, Hartati. 2000. Menejemen Tenaga Pendidikan. Yogyakarta: Gajahmada University Press

Sugiyono. 2012. Metode Penelitian Kuantitatif Kualitatif dan R\&D. Bandung: Alfabeta

Musfah, Jejen. 2017. Manajemen Pendidikan Teori, Kebijakan, dan Praktik. Jakarta: Kencana

Jauharotul M dan Mulyadi. 2017. Manajemen Pendidik dan tenaga Kependidikan di Madrasah Aliyah Negeri Kota Yogyakarta. Jurnal Akuntabilitas Manajemen Pendidikan Volume 5, No 2, September 2017 (161-173)

Bafadal, Ibrahim. 2003. Manajemen Peningkatan Mutu Sekolah Dasar, Dari Sentralisasi menuju Desentralisasi. Jakarta: Bumi Aksara.

Nasruji. 2017. Manajemen Pendidikan (Studi kasus Sekolah Menengah Atas Islam Terpadu Ulil Albab di Batam). Jurnal Program Studi Pendidikan Sejarah Volume 2, No 2 (52-62)
Muslimah. 2019. Rekrutmen Strategi Dalam Manajemen Sumber Daya Manusia. Jurnal At-Ta'lim, Vol 1 No 1, April 2019 (31-47)

Schaap, James Ike. 2019. The Peter Principle: Is This Phenomenonin Decline or Growing ? A review. The Journal of International Management Studies, Volume 14 Number 2, Auguzt, 2019. 